\title{
Changes in zinc and serum proteins due to carbon disulphide exposure
}

\author{
R. EL-GAZZAR, YASSIN M. EL-SADIK, and M. HUSSEIN \\ High Institute of Public Health, Occupational Health Department, Alexandria, Egypt
}

\begin{abstract}
El-Gazzar, R., El-Sadik, Y. M., and Hussein, M. (1973). British Journal of Industrial Medicine, 30, 284-288. Changes in zinc and serum proteins due to carbon disulphide exposure. Serum zinc and proteins have been studied in 82 workers in the Egyptian rayon industry, of whom $\mathbf{4 0}$ were at the time exposed to carbon disulphide $\left(\mathrm{CS}_{2}\right)$ and nine had been exposed in the past for a year or more. Thirty-three workers without exposure were used as controls. Carbon disulphide caused depletion of serum zinc by an increase in the rate of zinc excretion and an increase in all serum protein fractions. All these effects are temporary and improve on cessation of exposure.
\end{abstract}

Workers in rayon industries are liable to be exposed to carbon disulphide vapour during the different processes.

Carbon disulphide intoxication leads to metabolic disorders (McKee et al., 1943; Vigliani, 1954; Hernberg, Partanen, Nordman, and Sumari, 1970). Soucek (1957) believes that carbon disulphide entering the body is bound to amino acids to form dithiocarbamates and eventually thiazolidone. These newly formed substances are able to form nonionized complexes with polyvalent metal ions. Accordingly, chelation of some metal ions is to be expected, leading to their depletion. Disturbance to cellular metabolism and cell injury occur as a result of such depletion. Some authors (Cohen, Paulus, Keenan, and Scheel, 1958) consider that this chelation effect is a basic mechanism in carbon disulphide toxicity.

In carbon disulphide poisoning several enzymes, of which zinc is an integral part, are inhibited in vivo and in vitro (Madlo, Peizker, and Soucek, 1953; Vertin, 1967). Depletion of zinc from the body leads to several symptoms similar to those of carbon disulphide poisoning (Brieger, 1967). Furthermore, increased urinary zinc excretion in animals poisoned by carbon disulphide has been reported (Cohen et al., 1958; Scheel, 1967).

Abnormalities in zinc metabolism have been implicated in pathological and biochemical lesions in several human disorders. A close correlation has been observed between low serum zinc levels and diseases such as beri-beri, nephrosis, liver disorders, myocardial infarction, pneumonia, bronchitis, pernicious anaemia and leukaemia (Eggleton, 1939; Vallée, 1959; Talbot and Ross, 1960).

The physiological rôle of zinc may lie in one of its known functions as an integral part of many metalloenzymes as well as hormones (Vallée, 1955).

It has been found that the zinc ion forms stable complexes with many amino acids and proteins (Vallée and Altschule, 1949). Zinc exists in plasma in two forms-about one-third of total zinc as a firmly bound fraction attached to globulins, and a loosely bound fraction attached to albumin. Dennes, Tupper, and Wormall (1962) found that the part of zinc plasma attached to globulins is mainly with the alpha globulin fraction. Vallée (1959) predicted that zinc plays a cardinal rôle in protein and carbohydrate metabolism of human and animal pathology.

Because of these facts, the question is raised 
regarding the extent of the relationship between carbon disulphide exposure and changes in serum zinc. The objectives of the present study are to answer this question and to find the effect of carbon disulphide exposure on serum proteins as they are liable to be affected by changes in serum zinc.

There are two rayon plants in Egypt, one in Cairo where the line of flow is an enclosed one with no exposure to carbon disulphide except accidentally. The other is in Kafr El-Dawar, Alexandria, where this study was conducted.

\section{Materials and methods}

The study was carried out on a $20 \%$ random sample of available workers in the spinning department of a rayon viscose plant, where there is exposure to carbon disulphide of $5 \mathrm{ppm}$ to $40 \mathrm{ppm}$, with an occasional exposure of $105 \mathrm{ppm}$ beside the machines.

The threshold limit value (TLV) for carbon disulphide is $20 \mathrm{ppm}$ (American Conference of Governmental Industrial Hygienists, 1970). The sample comprised 82 male workers, of whom 40 were exposed to carbon disulphide and nine had previous exposure to carbon disulphide, but not for at least one year or more. The remaining 33 were non-exposed workers employed as guards or gardeners at the same factory, and who were of the same socio-economic standard and age distribution as the other men, and acted as a control group.

The mean ages of the exposed, previously exposed, and control groups were 40,39 , and 42 years and their mean weights were 71,73 , and $79 \mathrm{~kg}$ respectively. The mean work duration for the exposed group was 18 years. Those previously exposed to carbon disulphide had a mean duration of exposure of 10 years.

For each man in the sample a detailed occupational history was obtained and his body weight and height were recorded. A sample of about $10 \mathrm{ml}$ of blood was drawn by nitric acid $(2 \mathrm{~N})$ washed evacuated tubes specified for zinc. Serum was separated after clotting by centrifugation. A $20 \mathrm{ml}$ sample of urine was also collected in zinc-free plastic bottles.

Zinc levels in serum and urine were determined by the mixed colour method (Hoch and Vallée, 1949) after direct extraction with diphenylthiocarbazone in carbon tetrachloride. All precautions to avoid contamination were followed as specified by Malmström (1956). Urinary zinc determinations were carried out on $2 \mathrm{ml}$ of urine. Creatinine in urine was measured by the modified Folin alkaline picrate method (Varley, 1967) to make a correction for variability in urine concentration. Twentyfour-hour urine samples were not accepted because of their liability to contamination. All these analyses were done blind without knowledge of the men's exposure to carbon disulphide and the analyses were carried out for all groups at the same time.

Total serum proteins were estimated by the biuret method (Gornall, Bardawill, and David, 1949). Differential protein fractions were determined by electrophoresis using Whatman filter paper strips at pH 8.6 in $0.05 \mathrm{~mol} / 1$ barbitone buffer (Flynn and De Mayo, 1951).

Using the recorded heights and weights of the subjects, they were classified as under weight, normal, and over weight, (Wohl, 1960).

\section{Results and discussion}

The mean serum zinc level of the exposed men $(69.0 \mu \mathrm{g} \mathrm{\%})$ is lower than that of the controls (94.7 $\mu \mathrm{g} \mathrm{\% )} \mathrm{(Table} \mathrm{1).} \mathrm{The} \mathrm{difference} \mathrm{is} \mathrm{highly}$ significant $(t=5.82, \mathrm{P}<0.01)$. The mean serum zinc level for the group with previous exposure $(87.8 \mu \mathrm{g} \%)$ is lower than that for the controls but the difference is not statistically significant $(t=1.09$, $P<0.05)$. The difference in mean serum zinc levels between the exposed and those who were previously exposed is statistically significant $(t=3 \cdot 23$, $P<0.01)$. These findings therefore indicate that exposure to carbon disulphide decreases zinc levels in serum and that such an effect is a temporary one.

TABLE 1

Distribution OF WORKERS ACCORDING TO Serum Zinc Levels aNd EXPOSURE to Carbon Disulphide

\begin{tabular}{|c|c|c|c|c|c|c|}
\hline \multicolumn{4}{|c|}{ Serum zinc level $(\mu g \%)$} & \multirow{2}{*}{$\begin{array}{c}\text { Exposed } \\
30 \\
9 \\
1\end{array}$} & \multirow{2}{*}{$\begin{array}{c}\begin{array}{c}\text { Previous } \\
\text { exposure }\end{array} \\
3 \\
4 \\
2\end{array}$} & \multirow{2}{*}{$\begin{array}{c}\text { Controls } \\
9 \\
11 \\
13\end{array}$} \\
\hline $\begin{array}{l}80 \\
80-100 \\
100\end{array}$ & $\begin{array}{l}. \\
\cdots \\
.\end{array}$ & $\begin{array}{l}. \\
\cdots \\
.\end{array}$ & $\begin{array}{l}\cdots \\
\cdots \\
\cdots\end{array}$ & & & \\
\hline \multicolumn{3}{|c|}{ Total no. of men } & . & 40 & 9 & 33 \\
\hline \multicolumn{3}{|c|}{ Mean $^{1} \quad \ddot{\text { Standard deviation }}{ }^{1}$} & $\begin{array}{l}\cdots \\
\cdots\end{array}$ & $\begin{array}{l}69 \cdot 0 \\
16 \cdot 3\end{array}$ & $\begin{array}{l}87 \cdot 8 \\
15 \cdot 6\end{array}$ & $\begin{array}{l}94 \cdot 7 \\
20 \cdot 9\end{array}$ \\
\hline
\end{tabular}

${ }^{1}$ Mean and standard deviations are computed from the raw data.

The rate of zinc excretion in urine is higher among the exposed men $(525.05 \mu \mathrm{g} / \mathrm{g}$ creatinine) than in the controls $(353.8 \mu \mathrm{g} / \mathrm{g}$ creatinine) and in those who were previously exposed $(402.8 \mu \mathrm{g} / \mathrm{g}$ creatinine) (Table 2). This higher rate of zinc excretion in urine among the exposed group is statistically significant compared with that for the controls $(t=7 \cdot 40$, $P<0.01)$ and with that for the previously exposed men $(t=3.87, \mathrm{P}<0.01)$. The difference between the mean of those who were previously exposed and of the controls is not significant ( $P>0.05)$. Combining these findings, one can say that the lowered serum zinc level among the exposed is probably the result of a higher rate of urinary zinc excretion. Further, the increase in zinc excretion in urine can be attributed to carbon disulphide exposure and these effects are transient.

These findings confirm the hypothesis of Cohen et al. (1958) that such an effect is a temporary one which vanishes after interruption of the exposure.

Since the urinary zinc content depends on the serum zinc level, it was decided that a more thorough 
TABLE 2

DISTRIBUTION OF WORKERS ACCORDING TO URINE ZiNC LEVELS AND EXPOSURE TO CARBon Disulphide

\begin{tabular}{|c|c|c|c|c|c|c|}
\hline \multicolumn{4}{|c|}{$\begin{array}{l}\text { Urinary zinc level } \\
\text { ( } \mu \text { g/g creatinine })\end{array}$} & \multirow{2}{*}{$\begin{array}{c}\text { Exposed } \\
8 \\
17 \\
15\end{array}$} & \multirow{2}{*}{$\begin{array}{c}\begin{array}{c}\text { Previous } \\
\text { exposure }\end{array} \\
5 \\
4 \\
0\end{array}$} & \multirow{2}{*}{$\begin{array}{c}\text { Controls } \\
23 \\
10 \\
0\end{array}$} \\
\hline $\begin{array}{l}200- \\
400- \\
600+\end{array}$ & $\begin{array}{l}\cdots \\
\cdots \\
\cdots\end{array}$ & $\begin{array}{l}\ldots \\
\cdots \\
\ldots\end{array}$ & $\begin{array}{l}. \\
. \\
.\end{array}$ & & & \\
\hline \multicolumn{3}{|c|}{ Total no. of men } & . & 40 & 9 & 33 \\
\hline \multicolumn{3}{|c|}{$\operatorname{Mean}^{1}{ }_{\text {Standard deviation }}^{1}$} & $\begin{array}{l}\cdots \\
\cdots\end{array}$ & $\begin{array}{l}525 \cdot 05 \\
129 \cdot 3\end{array}$ & $\begin{array}{r}402 \cdot 8 \\
75 \cdot 5\end{array}$ & $\begin{array}{r}353 \cdot 8 \\
69 \cdot 9\end{array}$ \\
\hline
\end{tabular}

'Mean and standard deviations are computed from the raw data.

investigation of the interrelationship between serum zinc, urinary zinc, and exposure to carbon disulphide was required. For this purpose a detailed regression analysis of the data was done. However, before performing this analysis it was decided to pool the data of the previously exposed with the non-exposed to form a new control group. This seemed justifiable since the previous findings indicated no significant difference between these two groups, in addition to the fact that the number of previously exposed was rather small. In the regression analysis we considered the serum zinc level as the independent variable (X) and the urinary zinc level as the dependent variable (Y). A linear regression model was first fitted to the data which showed a difference between the exposed and the controls. However, the linear regression did not produce a good fit for the data, and it was therefore replaced by a curvilinear model including both linear $(\mathrm{X})$ and quadratic $\left(\mathrm{X}^{2}\right)$ values of the independent variable. This model produced a better fit (Table 3). From the values of the standard partial regression coefficients it can be seen that the relative strength of the relation between the urine zinc $(Y)$ and $X^{2}$ is stronger than with $X$, as indicated by the higher absolute value for the quadratic coefficients than for linear for both exposed and control groups. The resulting regression equations were as follows:

exposed: $\mathrm{Y}=383.81+5.561 \times-0.0489 \mathrm{X}^{2}$

controls: $\mathrm{Y}=218.78+3.670 \times-0.0218 \mathrm{X}$

where $Y$ is the expected urinary zinc and $X$ is a given value of serum zinc.

The figure shows the regression lines obtained from these equations which are clearly different for the exposed and the controls. Analysis of variance shows that the differences between 1egressions and adjusted means for the two groups are highly significant $(\mathrm{P}<0.01)$. These results coincide with those found by Cohen et al. (1959) and Scheel (1967).

Table 4 shows the means for serum zinc and the urinary zinc levels among the exposed group according to their work duration. These levels did not show any definite trend. The product correlation coefficient ( $r$ ) between serum zinc level and duration of work was $0 \cdot 196$. The value of $r$ between urine zinc

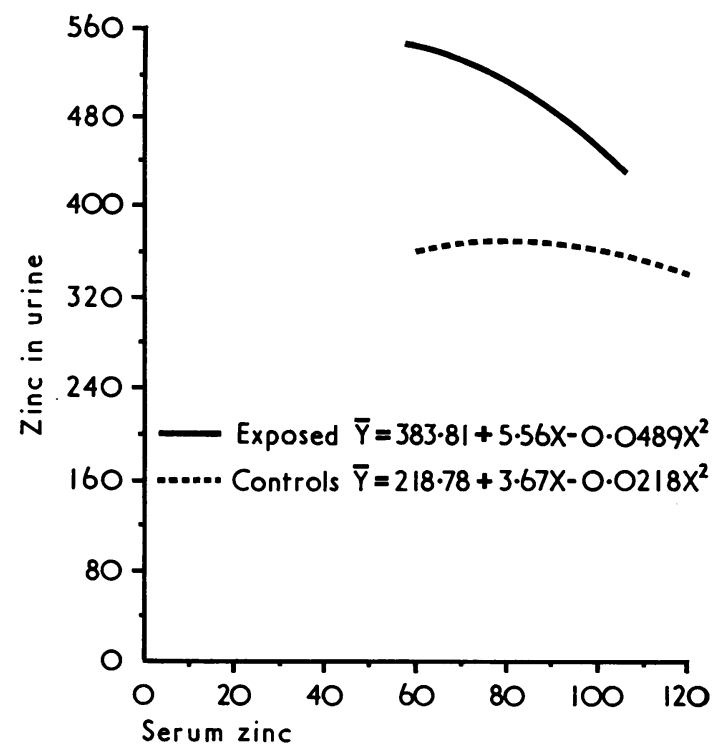

FIGURE. See text.

TABLE 3

Results of Regression Analysis for Urinary Zinc (Y) and Serum Zinc (X)

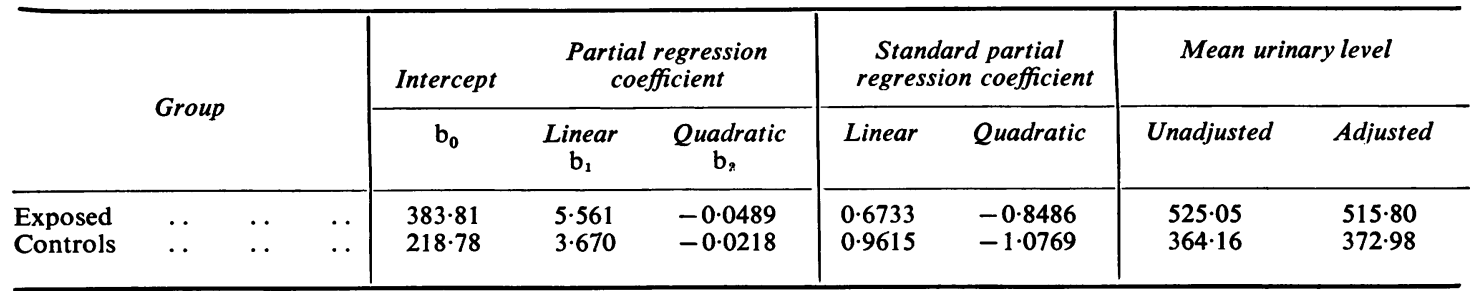


TABLE 4

SERUM AND URINARY ZiNC LeVELS ACCORDING to Duration of Exposure to Carbon DiSULPHIDE (EXPOSED GROUP)

\begin{tabular}{l|rrrrr}
\hline & \multicolumn{5}{|c}{ Duration of work $(y r)$} \\
\cline { 2 - 7 } & $<10$ & $10-$ & $15-$ & $20-$ & $25-30$ \\
\hline $\begin{array}{l}\text { No. of workers } \\
\text { Mean serum zinc }(\mu \mathrm{g} \%)\end{array}$ & 54 & 4 & 4 & 27 & 2 \\
\hline $\begin{array}{l}\text { Mean urinary zinc }(\mu \mathrm{g} / \mathrm{g} \\
\text { creatinine) }\end{array}$ & 490 & 391 & 425 & 530 & 734 \\
\hline
\end{tabular}

and duration of exposure was $0 \cdot 259$. Neither of these values is significantly different from zero ( $P>0.05)$. This means that duration of exposure does not affect the zinc levels in serum or the rate of its excretion in the urine.

This is not in fact acceptable because the daily exposure is variable for those who are exposed, and so duration of work cannot be considered alone for such a comparison. Weighted daily exposures for such individuals were difficult to obtain because workers do not always occupy the same job in the exposed area. In association with such variability in exposure, personal susceptibility may play a rôle. Another explanation which is plausible is that the effect of carbon disulphide exposure is an all or none effect which has no relationship to duration of exposure. This is substantiated by the findings that the previously exposed group is similar to the controls.

Among the exposed workers the mean of total serum proteins is $9.42 \mathrm{~g} \%$ (Table 5) which is significantly higher than that for the controls $(t=10.05$, $\mathbf{P}<0.01$ ). Also the difference in albumin, $\alpha_{1}, \alpha_{2}$, $\beta$ and $\gamma$ globulins is significantly higher among the exposed than the controls. Comparing the values for those previously exposed with those for the controls there is no significant difference except for gamma globulins $(t=2.75, \quad \mathrm{P}<0.05)$. The difference between the mean value for total proteins among those previously exposed and the controls is significantly higher $(t=2.40, \mathrm{P}<0.05)$. Thus from this table one can say that carbon disulphide exposure is associated with a disturbance in blood serum proteins in the form of an increase in both the albumin and globulin fractions. These changes except for the globulin fractions are transient in nature, as they become normal after cessation of exposure. Whether such an extensive effect of exposure is harmful or not needs further investigation including observations on blood osmotic pressure and cell metabolism.

It has been reported that in experimental animals serum zinc level affects body weight (El-Gazzar, 1965; Millar, Fischer, Elcoate, and Mawson, 1958). In our data a $\chi^{2}$ test showed no significant relationship between serum zinc and weight groups $\left(\chi^{2}=3.8, \mathrm{P}>0.05\right)$. Thus serum zinc could not be related to body weight, which may be due to the difference in workers' dietary habits and their activities.

\section{References}

American Conference of Governmental Industrial Hygienists (1970). 1014 Broadway, Cincinnati, Ohio, 4520?, U.S.A. Threshold Limit Values.

Brieger, H. (1967). Carbon disulphide in the living organism. In Toxicology of Carbon Disulphide: Proceedings of a Symposium, Prague, 1966, edited by $H$. Brieger and J. Teisinger, pp. 27-31. Excerpta Medica Foundation, Amsterdam.

Cohen, A. E., Paulus, H. J., Keenan, R. G., and Scheel, L. D. (1958). Skin absorption of carbon disulphide vapour in rabbits. A.M.A. Archives of Industrial Health, 17, 164-169.

—, Scheel, L. D., Kopp, J. F., Stockell, F. R., Keenan, R. G., Mountain, J. T., and Paulus, H. J. (1959). Biochemical mechanisms in chronic carbon disulphide poisoning. American Industrial Hygiene Association Journal, 20, 303-323.

Dennes, E., Tupper, R., and Wormall, A. (1962). Studies on zinc in blood, transport of zinc and incorporation of zinc in leucocytes. Biochemical Journal, 82, 466-476.

TABLE 5

Mean Values of Serum Proteins among Workers exposed to Carbon Disulphide ${ }^{1}$

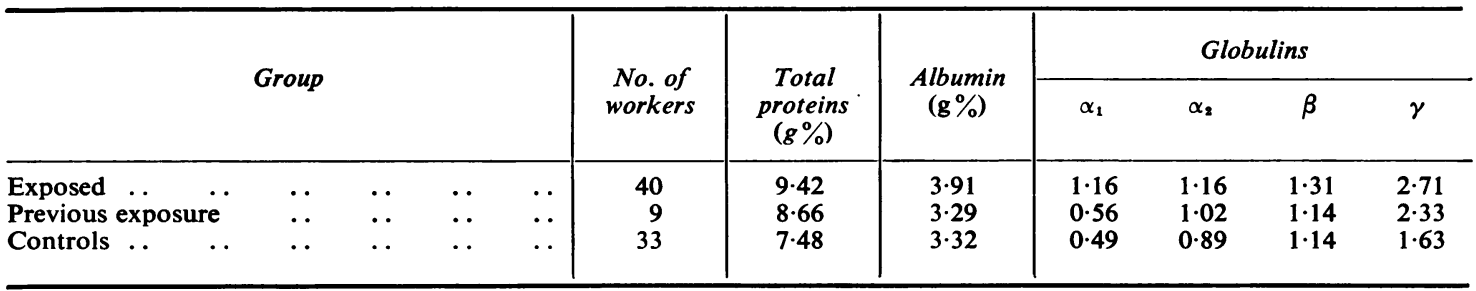

All workers are not dehydrate. 
Eggleton, W. G. (1939). Zinc content of epidermal structures in beriberi. Biochemical Journal, 33, 403-406.

El-Gazzar, R. (1965). Zinc deficiency in rats. Master's thesis, John's Hopkins University, School of Hygiene and Public Health.

Flynn, F. V., and De Mayo, P. (1951). Midroelectrophoresis of protein on filter-paper. Lancet, 261, 235-239.

Gornall, A. G., Bardawill, C. J., and David, M. M. (1949). Determination of serum proteins by means of biuret reaction. Journal of Biological Chemistry, 177, 751-766.

Hoch, F. L., and Vallée, B. L. (1949). Precipitation by trichloroacetic acid as a simplification in the determination of zinc in blood and its components. Journal of Biological Chemistry, 181, 295-306.

Hernberg, S., Partanen, T., Nordman, C-H., and Sumari, P. (1970). Coronary heart disease among workers exposed to carbon disulphide. British Journal of Industrial Medicine, 27, 313-325.

Madlo, Z., Peizker, Z., and Soucek, B. (1953). Absorption metabolism and action of carbon disulphide in the organism. Effect of carbon disulphide in tissue respiration. Pracovni Lékařstvi, 5, 263-268.

Malström, B. G. (1956). Determination of zinc in biological materials. In Methods of Biochemical Analysis, edited by D. Glick, vol. 3, pp. 327-352. Interscience Publishers, New York.

McKee, R. W., Kiper, C., Fountain, J. H., Risken, A. M., and Drinker, P. (1943). A solvent vapour, carbon disulphide. Absorption, elimination, metabolism and mode of action. Journal of the American Medical Association, 122, 217-222.

Millar, M. J., Fischer, M. I., Elcoate, P. V., and Mawson, C. A. (1958). Effects of dietary zinc deficiency on reproductive system of male rats. Canadian Journal of Biochemistry, 36, 557-569.
Scheel, L. D. (1967). Experimental carbon disulfide poisoning in rabbits; its mechanism and similarities with human case reports. In Toxicology of Carbon Disulphide: Proceedings of a Symposium, Prague, 1966, edited by H. Brieger and J. Teisinger, pp. 107-117. Excerpta Medica Foundation, Amsterdam.

Soucek, B. (1957). Unwandlung von Schwefelkohlenstoff im Organismus. Journal of Hygiene, Epidemiology, Microbiology and Immunology, 1, 10-22.

Talbot, T. R., and Ross, J. F. (1960). The zinc content of plasma and erythrocytes of patients with pernicious anemia, sickle cell anemia, polycythemia vera, leukemia and neoplastic diseases. Laboratory Investigation, 9, 174-184.

Vallée, B. L. (1955). Zinc and metalloenzymes. In Advances in Protein Chemistry, edited by M. L. Anson, V. Bailey, and J. T. Edsalb, pp. 317-384. Academic Press, New York. (1959). Biochemistry, physiology and pathology of zinc. Physiological Reviews, 39, 443-490.

- , and Altschule, M. D. (1949). Zinc in the mammalian organisms, with particular reference to carbonic anhydrase. Physiological Reviews, 29, 370-388.

Varley, H. (1967). Practical Clinical Biochemistry, 4th ed., pp. 198-199. Heinemann, London, and Interscience Books Inc., New York.

Vertin, P. G. (1967). Biochemical and clinical studies of the pathophysiology of carbon disulphide. In Toxicology of Carbon Disulphide: Proceedings of a Symposium, Prague, 1966, edited by H. Brieger and J. Teisinger, pp. 94-99. Excerpta Medica Foundation, Amsterdam.

Vigliani, E. C. (1954). Carbon disulphide poisoning in viscose rayon factories. British Journal of Industrial Medicine, 11, 235-240.

Wohl, M. G. (1960). In Modern Nutrition in Health and Disease, edited by N. G. Wohl and R. S. Goodhart, 2nd ed., p. 863. Lea and Febiger, Philadelphia.

Received for publication 15 June, 1972.

Accepted for publication 5 January, 1973. 